\title{
Development of value addition of pineapple (Ananas comosus) chunks using solar dehydration technology
}

\begin{abstract}
Osmotic dehydration is a method for the partial dehydration of water rich foods and has received greater attention in recent years as an effective method for preservation of fruits and vegetables. Being a simple process, it facilitates processing of fruits and vegetables such as banana, sapota, fig, guava, pineapple, apple, mango, grapes, carrots, pumpkins, etc. with retention of initial fruit characteristics viz., color, aroma, texture and nutritional composition. It is less energy intensive than any other drying technique. Thus the objective of this study was to develop the pineapple chunks using Osmo solar dehydration technique. With this objective, the study was conducted to develop Osmo - solar dried pineapple (Ananas comosus), with 9 sunny hours (cabinet temp. $50^{\circ} \mathrm{C}-55^{\circ} \mathrm{C}$ ) of drying time with a yield of $21.460 \%$, and $11.282 \%$ moisture content in the product. The product was packed into two different packaging material viz., Aluminium and Polypropylene pouches. Physico-chemical characteristics and nutritional parameters along with microbiological quality and shelf life at ambient and accelerated conditions for 60days were studied. The result showed that the sugar content in Osmo solar was high (68.499) when compared to fresh fruit (10.788) due to the overnight dip in osmotic solution. The sensory scores showed that the samples in aluminium pouch were superior in appearance and taste when compared to polypropylene pouch samples after 60days of storage. It can be concluded that Osmo solar dehydration technique seems to be the best method for dehydrating pineapple chunks and is found to be shelf stable for a period of 60days which is equivalent to 6 months. This product can also be used as snack food where the Osmo solar dehydrated pineapple chunks are embedded with chocolate coating in order to increase its acceptability.
\end{abstract}

Volume 4 Issue I - 2017

\author{
Jangabelli Mounika,' M Ramakrishna Rao, ${ }^{2} \mathrm{~V}$ \\ Bhasker,' Kavita Waghray,' Srinivas Maloo' \\ 'Department of Food Technology, Osmania University, India \\ ${ }^{2}$ Founder and Director of Society for Energy, Environment \& \\ Development (SEED), India
}

Correspondence: Jangabelli Mounika, Department of Food Technology, University College of Technology, Osmania University, Hyderabad, T.S, India,

Email mounika.fpt.ou@gmail.com

Received: July 21, 2016 | Published: January 09, 2017

\section{Introduction}

The pineapple (Ananas comosus) is a tropical plant with edible multiple fruit consisting of coalesced berries, and the most economically significant plant in the Bromeliaceae family. Pineapples may be cultivated from a crown cutting of the fruit, possibly flowering in 20-24months and fruiting in the following six months.

The pineapple is herbaceous perennial which grows to 1.0 to 1.5 meters tall. In appearance, the plant itself has a short, stocky stem with tough, waxy leaves. When creating its fruit, it usually produces up to 200 flowers. Once it flowers, the individual fruits of the flowers join together to create a pineapple. After the first fruit is produced, side shoots (called 'suckers' by commercial growers) are produced in the leaf axils of the main stem. These may be removed for propagation, or left to produce additional fruits on the original plant (Figure 1).

Pineapples are consumed fresh, cooked, juiced, and preserved, and are found in a wide array of cuisines. In addition to consumption, in the Philippines the pineapple's leaves are used to produce the textile fiber employed as a component of wall paper and furnishings, amongst other uses. Pineapple is low in calories, sodium, saturated fats and cholesterol while being a rich source of fibre, so it's the perfect weight loss food. It is an excellent source of Vitamin $\mathrm{C}$ and other antioxidants essential for collagen synthesis; Vitamin $\mathrm{C}$ also helps to maintain the integrity of blood vessels, skin, organs and bones and also it is a rich source of Vitamin A and Beta-Carotene, which helps immune system, eyesight and protects from free radicals; Vitamins B1 and B6 which are good for energy production and the breakdown of sugars and starches in digestive system; copper, which helps red blood cell synthesis; and potassium, which assists in controlling the heart rate and blood. Pineapple is also known for its high level of manganese. The Manganese mineral is an essential element for energy production, while protecting cells from free radicals. It helps the body to use key nutrients including thiamine and biotin, keeps your bones healthy and helps synthesize fatty foods.

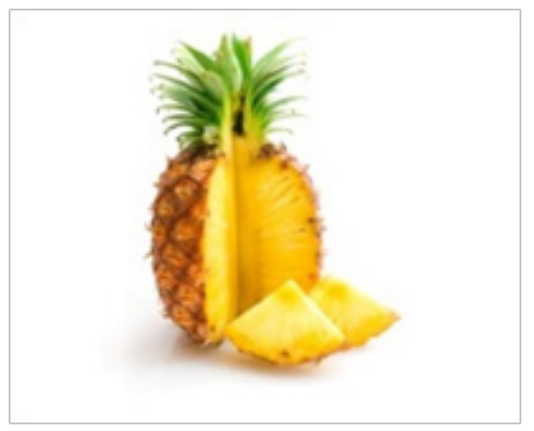

Figure I Pineapple.

The aim of this study is to enhance the shelf life of the Pineapple by processing it into a value added dry fruit chunks by using Osmo solar dehydration technology which can be rehydrated and used in fruit salads, laddus, bakery and confectionary items. 


\section{Materials and methods}

\section{Raw materials}

Pineapple Fruits, Sugar, Potassium metabisulphite and citric acid.

\section{Equipment \& miscellaneous}

Gas Stove with Cylinder, Flame Kettle provided with stirrer, Stainless steel utensils, stainless steel knives and peelers, Solar Dryer, Containers, Sealing Machine and Flexible packing materials.

Process procedure for osmo-solar dehydration of pineapple fruit slices

\section{Flow chart}

Procurement of pineapple from local markets

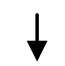

Selection of Matured but not fully ripened pineapple fruits

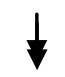

Sorting \& Grading based on quality and physical appearance

Washing for 2 to 3 times to remove adhering dust, chemicals etc.

Remove the crown and outer skin using stainless steel knives

Slice with stainless steel Knives in to small slices

Steam blanching the slices for 3-5minutes and immediately transfer into cold water to prevent over cooking

\section{$\downarrow$}

Transfer the slices in Sucrose solution of $70^{\circ}$ Brix (1:3 Ratio) for overnight

Remove the Slices and wash with water quickly to remove adhering sugar syrup

\section{$\downarrow$}

Dry in a solar cabinet air dryer to a moisture content of $11 \%$ for 9hours

Store the dried slices in air tight container for 2 to 3 days for sweating to equilibrate the moisture levels in the slices

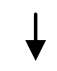

Immediately pack the slices in Standby pouches (Aluminium and Polypropylene) and label

Store in cool and dry place.

\section{Osmotic dehydration}

Osmotic dehydration is the process of water removal from fruits and vegetables, because the cell membranes are semi-permeable and allow water to pass through them more rapidly than sugar. During osmosis small quantity of fruit acid is removed along with water. It is a dynamic process, in which water and acid are removed at first and then move slowly, while sugar penetration is very slight at first but increases with the time. Therefore, the characteristics of the product can be varied by controlling temperature, sugar syrup concentration, time of osmosis etc. to make dehydration process faster. ${ }^{1-5}$

\section{Storage}

The storage evaluation for Osmo-solar dehydrated pineapple chunks $\left(70^{\circ} \mathrm{B}\right)$ was carried out at two different conditions i.e., Ambient (Amb) storage conditions $\left(37^{\circ} \mathrm{C}, 65 \% \mathrm{RH}\right)$ and Accelerated (Acc) storage conditions $\left(60^{\circ} \mathrm{C}, 95 \% \mathrm{RH}\right)$ in two different packaging materials i.e. Aluminium (Al) and Polypropylene (PP) for a period of about 6 months and the product is tested in all aspects for the assurance of its acceptability and storage.

\section{Results and Discussion}

Osmotic dehydration process was alone time consuming, laborious and the product is too sweet like candy. Hence in order to reduce process time and energy saving the new method of Osmosolar dehydration was taken up as new method of dehydration. Partial osmotic dehydration followed by solar dehydration is termed as Osmo-solar dehydration. In Osmo-solar dehydration fruits are initially subjected to osmosis by dipping in sugar syrup (osmotic agent) then the fruits are dried in a solar dryer till the acceptable moisture content is achieved. This method is most suitable for fruits guava, pine apple, banana, mango, sapota, papaya, apple and other tropical fruits.

\section{Drying data}

First, a comparative study was carried out to evaluate the best drying technique for dehydration of pineapple in terms of drying time, yield obtained, nutritive and sensory properties. Solar dehydrated pineapple chunks and Osmo - solar dehydrated pineapple slices of $60^{\circ} \mathrm{B}$ (sugar syrup with $60^{\circ} \mathrm{Brix}+0.1 \% \mathrm{KMS}+0.2 \%$ Citric acid) were inferior in its quality and sensory properties when compared to the Osmo solar dehydrated pineapple chunks using osmotic solution (sugar syrup with $70^{\circ} \mathrm{Brix}+0.1 \% \mathrm{KMS}+0.2 \%$ Citric acid). $30 \%$ of the moisture content was removed during osmosis in Osmo solar dehydrated pineapple of $70^{\circ}$ Brix as the pineapple slices were soaked in the osmotic solution overnight (for about $9 \mathrm{hrs}$ ), ultimately reducing the drying time in the solar drier. The drying data is tabulated as follow (Table 1):

\section{Physico chemical parameters}

Knowledge of the physico-chemical properties of food is fundamental in analyzing the characteristics of food during its processing. The study of these food properties and their responses to process conditions are necessary because they influence the treatment received during the processing and also because they are good indicators of other properties and qualities of food. In the present investigation certain physico-chemical properties of the developed product were analyzed to ensure the quality of the products which includes estimation of moisture content, acidity, brix, sugar content as well as browning index. The result shown that the sugar content in Osmo solar was high (68.499) when compared to fresh fruit (10.788) due to the overnight dip in osmotic solution and the moisture content in solar dehydrated pineapple chunks is less (11.282) compared to the fresh pineapple. All the data is tabulated and the results are as follow (Table 2). 


\section{Nutritional parameters}

Pineapple is a good source of Sodium, Vitamin - C and Vitamin - A. The nutrient parameters which were analyzed include total carotenoids, vitamin $\mathrm{C}$, total phenols and flavonoids, and minerals such as potassium, sodium, iron, crude fibre and fat. The results indicated that by using Osmo solar dehydration technique many of the nutrients could be retained with less energy consumption. The final product was acceptable in terms of nutritive value also and the results are tabulated as follows (Table 3 \& Graph 2):

\section{Microbial assay}

Measured volume of different dilutions of samples were plated on suitable nutrient media, such as nutrient agar or yeast extract agar plates, incubated at $37^{\circ} \mathrm{C}$ for about 48 hours and the number of colonies were counted. The total viable count per milliliter or gram was calculated (Table 4).

\section{Sensory evaluation}

The sensory evaluation of dehydrated pineapple chunks was carried out on a 9-point hedonic scale rating by 10 semi-trained panelists to know the acceptability of the product.

This sensory evaluation was helped in ensuring the quality of the product. The panel members were asked to evaluate color, appearance, flavor, taste, texture and overall acceptability by scoring rate of

9-Like extremely,
8-Like very much,

7-Like moderately,

6-Like slightly,

5-Neither like nor dislike,

4-Dislike slightly,

3-Dislike moderately,

2-Dislike very much,

1-Dislike very much.

Finally a conclusion was made by doing average of all scores for each attribute. Mean scores of sensory evaluation are presented in the Table 5. The results showed that Aluminium packed Osmo solar dehydrated Pineapple chunks were more acceptable in terms of color, appearance and taste when compared with the Polypropylene packed Osmo solar dehydrated Pineapple chunks (Table 5 \& Graph 3).

Comparative sensory evaluation on Osmo solar dried pineapple chunks and Osmo solar dried pineapple embedded chocolate was conducted by 10 semi trained panel members. Results shown that in taste, flavor and overall acceptability of Osmo solar dried pineapple embedded chocolate were superior to Osmo solar dried pineapple. Hence, Osmo solar dehydrated pineapple chunks can be used as a snack food and also, it can be embedded into the chocolates in order to increase its acceptance. ${ }^{6-10}$ Results are tabulated as follows Table 6:

Table I Drying data for pineapple chunks

\begin{tabular}{|c|c|c|c|c|c|c|c|}
\hline \multirow{2}{*}{$\begin{array}{l}\text { S. } \\
\text { no }\end{array}$} & \multirow[b]{2}{*}{ Name of the product } & \multicolumn{4}{|l|}{ Drying conditions } & \multicolumn{2}{|c|}{ Finished product } \\
\hline & & $\begin{array}{l}\text { Loading capacity } \\
\left(\mathrm{kg} / \mathrm{m}^{2}\right)\end{array}$ & $\begin{array}{l}\text { Ambient temp } \\
\left({ }^{\circ} \mathrm{C}\right)\end{array}$ & $\begin{array}{l}\text { Cabinet temp } \\
\left({ }^{\circ} \mathrm{C}\right)\end{array}$ & $\begin{array}{l}\text { Time } \\
\text { (hrs) }\end{array}$ & $\%$ Moisture & $\%$ Yield \\
\hline 1 & $\begin{array}{l}\text { Solar dehydrated Pineapple } \\
\text { chunks }\end{array}$ & 5 & $32.3-39.6$ & $41-55$ & 15 & 12.256 & 11.25 \\
\hline 2 & $\begin{array}{l}\text { Osmo solar dehydrated } \\
\text { pineapple chunks }\left(60^{\circ} \mathrm{B}\right)\end{array}$ & 5 & $32.3-39.6$ & $41-55$ & 11 & 11.475 & 11.475 \\
\hline 3 & $\begin{array}{l}\text { Osmo solar dehydrated } \\
\text { pineapple chunks }\left(70^{\circ} \mathrm{B}\right)\end{array}$ & 5 & $32.3-39.6$ & $41-55$ & 9 & 11.282 & 21.46 \\
\hline
\end{tabular}

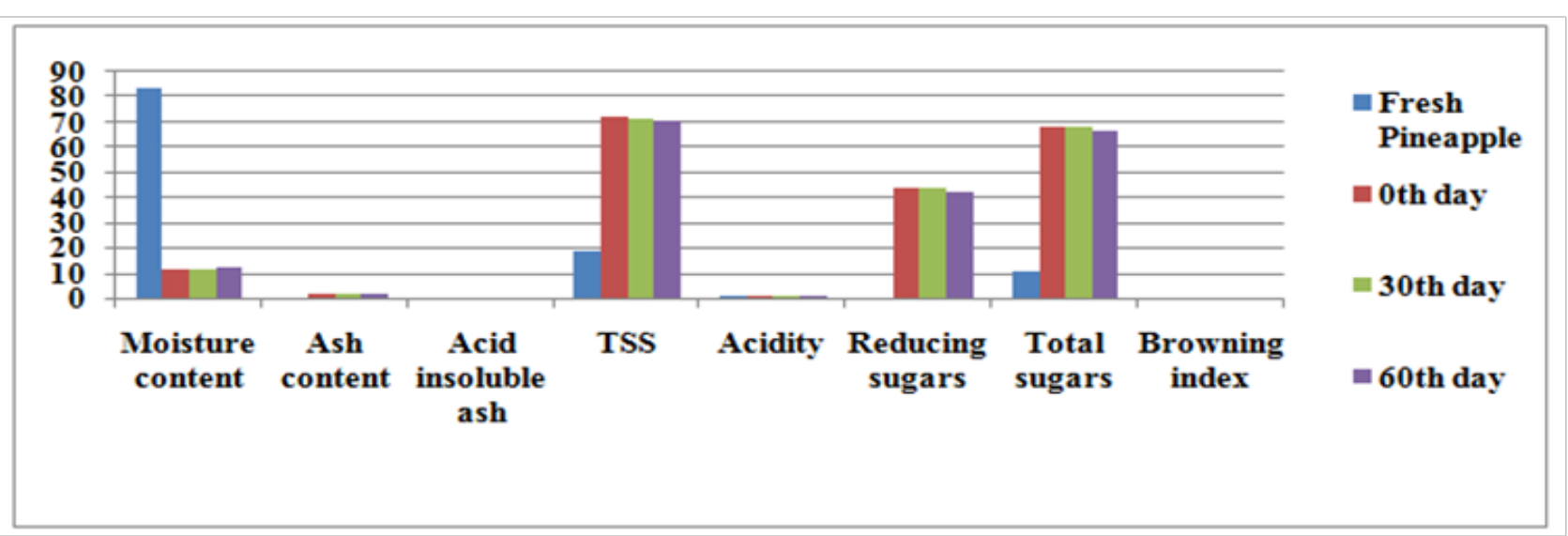

Graph I Comparison graph on physico chemical parameters of pineapple chunks packed in aluminium pouch at ambient storage conditions. 
Table 2 Comparative study on physico chemical parameters of fresh pineapple and dehydrated pineapple chunks in two different packaging materials

\begin{tabular}{|c|c|c|c|c|c|c|c|c|c|c|}
\hline \multirow{2}{*}{ Parameters } & \multirow{2}{*}{$\begin{array}{l}\text { Fresh } \\
\text { fruit }\end{array}$} & \multirow[b]{2}{*}{$0^{\text {th }}$ Day } & \multicolumn{4}{|c|}{ 30 ${ }^{\text {th }}$ Day } & \multicolumn{4}{|c|}{$60^{\text {th }}$ Day } \\
\hline & & & $\begin{array}{l}\text { Amb } \\
\text { (Al) }\end{array}$ & $\begin{array}{l}\text { Amb } \\
(\mathbf{P P})\end{array}$ & $\begin{array}{l}\text { Acc } \\
\text { (Al) }\end{array}$ & $\begin{array}{l}\text { Acc } \\
(\mathbf{P P})\end{array}$ & $\begin{array}{l}\text { Amb } \\
\text { (Al) }\end{array}$ & $\begin{array}{l}\text { Amb } \\
(\mathbf{P P})\end{array}$ & $\begin{array}{l}\text { Acc } \\
\text { (AI) }\end{array}$ & $\begin{array}{l}\text { Acc } \\
(\mathbf{P P})\end{array}$ \\
\hline Moisture Content (\%) & 83.74 & 11.282 & 11.76 & 11.98 & 12.017 & 12.569 & 12.258 & 12.784 & 12.972 & 13.02 \\
\hline Ash (\%) & 0.368 & 1.42 & 1.44 & 1.46 & 1.45 & 1.46 & 1.47 & 1.49 & 1.46 & 1.48 \\
\hline Acid insoluble ash (\%) & 0.119 & 0.198 & 0.199 & 0.198 & 0.197 & 0.197 & 0.121 & 0.121 & 0.122 & 0.123 \\
\hline $\begin{array}{l}\text { Total soluble solids } \\
(\%)\end{array}$ & 18.34 & 71.876 & 71.26 & 71.16 & 71.198 & 71.167 & 70.867 & 70.856 & 70.939 & 70.93 \\
\hline $\begin{array}{l}\text { Acidity }(\%) \\
\text { (as citric acid) }\end{array}$ & 0.798 & 0.955 & 0.922 & 0.921 & 0.916 & 0.911 & 0.9185 & 0.9112 & 0.918 & 0.912 \\
\hline Browning Index $(\lambda)$ & 0.449 & 0.489 & 0.557 & 0.577 & 0.586 & 0.591 & 0.587 & 0.594 & 0.581 & 0.590 \\
\hline Reducing Sugars (\%) & 0.368 & 43.829 & 43.50 & 43.43 & 44.378 & 43.314 & 42.343 & 42.341 & 42.419 & 42.47 \\
\hline Total sugars (\%) & 10.78 & 68.499 & 67.89 & 67.17 & 67.533 & 67.139 & 66.475 & 66.486 & 66.479 & 65.86 \\
\hline
\end{tabular}

Table 3 Comparative study on nutritional parameters of fresh pineapple and dehydrated pineapple chunks in two different packaging materials

\begin{tabular}{|c|c|c|c|c|c|c|c|c|c|c|}
\hline \multirow[b]{2}{*}{ Parameters } & \multirow[b]{2}{*}{$\begin{array}{l}\text { Fresh } \\
\text { Fruit }\end{array}$} & \multirow[b]{2}{*}{$0^{\text {th }}$ Day } & \multicolumn{2}{|c|}{$30^{\text {th }}$ Day } & \multirow[b]{2}{*}{$\begin{array}{l}\text { Acc } \\
\text { (AI) }\end{array}$} & \multirow[b]{2}{*}{$\begin{array}{l}\text { Acc } \\
(\mathbf{P P})\end{array}$} & \multicolumn{3}{|c|}{$60^{\text {th }}$ Day } & \multirow[b]{2}{*}{$\begin{array}{l}\text { Acc } \\
(\text { PP) }\end{array}$} \\
\hline & & & $\begin{array}{l}\text { Amb } \\
\text { (Al) }\end{array}$ & $\begin{array}{l}\text { Amb } \\
(\mathbf{P P})\end{array}$ & & & $\begin{array}{l}\text { Amb } \\
\text { (Al) }\end{array}$ & $\begin{array}{l}\text { Amb } \\
(\mathbf{P P})\end{array}$ & $\begin{array}{l}\text { Acc } \\
\text { (AI) }\end{array}$ & \\
\hline $\begin{array}{l}\text { Vitamin }-\mathrm{C} \\
(\mathrm{mg} / 100 \mathrm{~g})\end{array}$ & 39 & 41.35 & 35.14 & 35.05 & 31.98 & 31.94 & 28.01 & 27.98 & 26.493 & 36.441 \\
\hline $\begin{array}{l}\text { Carotenoids } \\
(\mu \mathrm{g} / 100 \mathrm{~g})\end{array}$ & 18 & 38.25 & 31.87 & 30.36 & 29.25 & 28.23 & 25.71 & 27.19 & 27.39 & 27.588 \\
\hline Crude fiber (\%) & 0.790 & 0.817 & 0.821 & 0.814 & 0.816 & 0.826 & 0.838 & 0.831 & 0.814 & 0.817 \\
\hline Crude fat $(\%)$ & 0.132 & 1.624 & 1.643 & 1.659 & 1.631 & 1.659 & 1.632 & 1.642 & 1.641 & 1.642 \\
\hline Phenols $(\mu \mathrm{g} / \mathrm{g})$ & 71.782 & 289.71 & 249.15 & 247.25 & 238.17 & 232.13 & 207.26 & 206.18 & 204.47 & 206.93 \\
\hline Flavonoids $(\mu \mathrm{g} / \mathrm{g})$ & 0.8449 & 9.628 & 7.925 & 7.165 & 5.712 & 5.415 & 5.101 & 5.262 & 4.402 & 4.005 \\
\hline Sodium(mg/100g) & 34.7 & 68.01 & 67.23 & 67.59 & 67.25 & 66.89 & 66.45 & 66.78 & 66.85 & 66.65 \\
\hline Iron(mg/100g) & 2.42 & 8.96 & 8.75 & 8.75 & 8.49 & 8.56 & 8.66 & 8.64 & 8.44 & 8.26 \\
\hline
\end{tabular}

Table 4 Comparative study on microbial parameters of fresh pineapple and dehydrated pineapple chunks in two different packaging materials

\begin{tabular}{|c|c|c|c|c|c|c|c|c|c|c|c|}
\hline \multirow{3}{*}{ S. no } & \multirow{3}{*}{ Microbial parameter } & \multirow{3}{*}{ Fresh fruit } & \multirow{3}{*}{$0^{\text {th }}$ day } & \multicolumn{4}{|c|}{$3^{\text {th }}$ Day } & \multicolumn{4}{|c|}{$60^{\text {th }}$ Day } \\
\hline & & & & Amb & Amb & Acc & Acc & Amb & Amb & Acc & Acc \\
\hline & & & & (Al) & (PP) & (Al) & (PP) & (Al) & (PP) & (AI) & (PP) \\
\hline 1 & Total plate count & 1200 & Nil & Nil & Nil & Nil & Nil & Nil & Nil & Nil & Nil \\
\hline 2 & E. coli & Nil & Nil & Nil & Nil & Nil & Nil & Nil & Nil & Nil & Nil \\
\hline
\end{tabular}


Table 5 Comparative study on sensory properties of osmo solar dehydrated pineapple chunks packed in aluminium and polypropylene pouches and stored at ambient and accelerated storage conditions

\begin{tabular}{|c|c|c|c|c|c|c|c|c|c|c|}
\hline \multirow[b]{2}{*}{ S. no } & \multirow[b]{2}{*}{ Parameter } & \multirow[b]{2}{*}{$0^{\text {th }}$ Day } & \multicolumn{4}{|c|}{ 30 ${ }^{\text {th }}$ Day } & \multicolumn{4}{|c|}{$60^{\text {th }}$ Day } \\
\hline & & & $\begin{array}{l}\text { Amb } \\
\text { (Al) }\end{array}$ & $\begin{array}{l}\text { Amb } \\
(P P)\end{array}$ & $\begin{array}{l}\text { Acc } \\
\text { (Al) }\end{array}$ & $\begin{array}{l}\text { Acc } \\
(\mathbf{P P})\end{array}$ & $\begin{array}{l}\text { Amb } \\
\text { (Al) }\end{array}$ & $\begin{array}{l}\text { Amb } \\
(P P)\end{array}$ & $\begin{array}{l}\text { Acc } \\
\text { (AI) }\end{array}$ & $\begin{array}{l}\text { Acc } \\
\text { (PP) }\end{array}$ \\
\hline 1 & Colour & 8 & 8 & 7.5 & 8 & 7.5 & 8 & 7.5 & 8 & 7 \\
\hline 2 & Appearance & 8 & 7.5 & 7.5 & 8 & 8 & 7.4 & 7.4 & 7.5 & 7.5 \\
\hline 3 & Taste & 8 & 8 & 8 & 8 & 8 & 8 & 7.8 & 7.5 & 7.8 \\
\hline 4 & Texture & 7.9 & 7.8 & 7.8 & 7.8 & 7.8 & 7.5 & 7.5 & 7.5 & 7.5 \\
\hline 5 & Flavour & 8 & 8 & 8 & 8 & 8 & 7.8 & 7.4 & 8 & 7.7 \\
\hline 6 & Overall acceptability & 8 & 8 & 8 & 8 & 7.8 & 8 & 7.7 & 7.7 & 7.6 \\
\hline
\end{tabular}

Table 6 Comparative study on sensory properties of osmo solar dehydrated pineapple chunks packed in aluminium pouch and polypropylene pouches

\begin{tabular}{llll}
\hline S. no & Parameter & Osmo solar dried pineapple & Fruit embedded chocolate \\
\hline 1. & Colour & 8 & 8 \\
2. & Appearance & 7.9 & 8 \\
3. & Taste & 7.9 & 8 \\
4. & Texture & 7.5 & 8 \\
5. & Flavour & 7.5 & 7.8 \\
6. & Overall acceptability & 7.8 & 8 \\
\hline
\end{tabular}

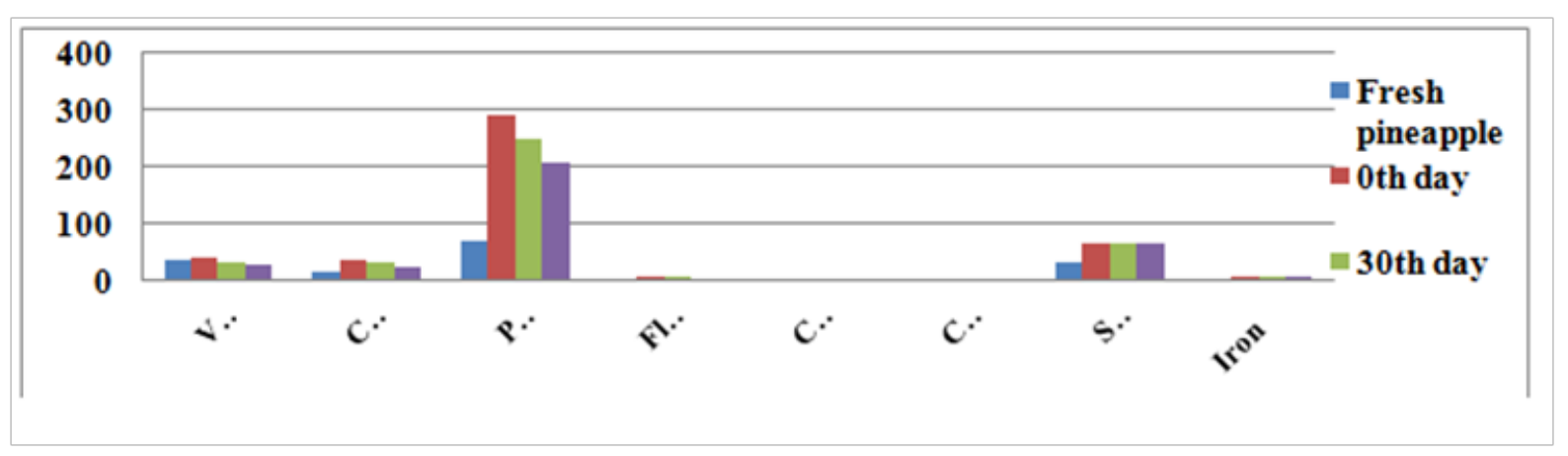

Graph 2 Comparison graph on nutritional parameters of pineapple chunks packed in aluminium pouch at ambient storage condition.

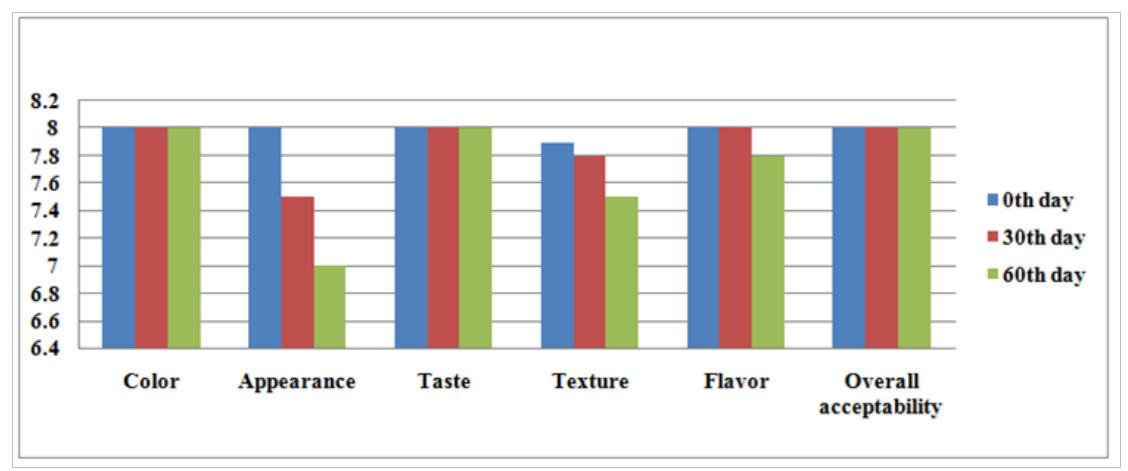

Graph 3 Comparison graph on osmo solar dried pineapple chunks in aluminium package at ambient storage conditions. 


\section{Conclusion}

From the above study on dehydration of pineapple using two dehydration methods like solar dehydration and Osmo solar dehydration, we can conclude that Osmo-solar dehydrated pineapple chunks packed in aluminium pouch was good in all aspects like physico chemical, nutritional properties and sensory evaluation with an overall sensory score of 8 on a scale of 9 . Based on the microbial analysis, there was no colonies found in Osmo-solar dehydrated pineapple chunks as aqueous sugar solution is used for dipping the chunks overnight for partial dehydration which acts as the natural Preservative and hence, the product is also safe in microbial aspects. Aluminium packaging is best suitable in terms of retaining the color and appearance of the product and some of the nutritional, physico chemical and sensory properties too with 7.9 sensory score whereas samples in polypropylene pouch stand at 7.5 sensory score. Thus it can be concluded that Osmo-solar dehydrated pineapple packed in aluminium pouch is best in shelf stability for a period of 6 months.

\section{Acknowledgements}

I express my sincere gratitude to Prof. M.RAMAKRISHNA RAO, Head of the organization, and Ms. R. SHYAMALA General Secretary, Society for Energy, Environment and Development (SEED), Hyderabad for providing me an opportunity to carry out this project. It's my pleasure to thank Dr. SURESH, Dr. M.M. Krishna and Dr. K. Vidyasagar for their support and guidance and also Ms. P. Aparna, Mrs. B. Bharathi, and Mrs. A. Sunitha, R\&D staff in Society for Energy, Environment and Development (SEED) who offered their valuable time and guidance, with which I could complete my work. I would like to thank Dr. Kavita Waghray and Asst Prof. V. Bhasker for their continuos support and guidance to achieve this endeavor.

\section{Conflict of interest}

The author declares no conflict of interest.

\section{References}

1. AOAC. Official methods of analysis of the Association of Official Analytical Chemists. 14th ed. Washington DC, USA; 1984.

2. S Ranganna. Handbook of Analysis and Quality Control for Fruit and Vegetable Products. 2nd ed. Trove; 1986. 1112 p.

3. UD Chavan, R Amarowicz. osmotic dehydration process for preservation of fruits and vegetables. Journal of food research. 2012;1(2):202-209.

4. Fasogbon BM. Studies on the Osmotic Dehydration and Rehydration characteristics of pineapple slices. Journal of Food Process Technology. 2013;4:4.

5. BK Bala, MRA Mondol, BK Biswas, et al. Solar drying of pineapple using solar tunnel drier. Renewable energy. 2001;28(2):183-190.

6. Ghan Shyam Abrol, Devina Vaidya, Ambika Sharma, et al. Effect of Solar Drying on Physico-chemical and Antioxidant Properties of Mango, Banana and Papaya. National Academy Science Letters. 2013;37(1):51-57.

7. JH Moy, MJL Kuo. Solar osmovac-dehydration of papaya. Journal of Food Process Engineering. 1985;8(1):23-32.

8. Laura A, Ramalloand Rodolfo H, Mascheroni. Rate of water loss and sugar uptake during the osmotic dehydration of pineapple. Brazilian Archives of Biology and Technology. 2005;48(5):761-770.

9. Lerici CR, Pinnavaia G, Rosa DM, et al. Osmotic dehydration of fruit: influence of osmotic agents on drying behaviour and product quality. $J$ Food Sci. 1985;50(5):1217-1219.

10. Taiwo KA, Angersbach A, Knorr D. Rehydration studies on pretreated and osmotically dehydrated apple slices. J Food Sci. 2002;67(2):842-847. 